\title{
BUSINESS INTELLIGENCE AND IPAD TECHNOLOGY RAISING THE BAR IN PUBLIC EDUCATION: A QUANTITATIVE STUDY
}

\author{
Joseph Compomizzi, Florida Atlantic University, jcompomizzi@fau.edu \\ Shana M. D'Aurora, Steubenville City Schools, sdaurora@scsohio.org \\ Bryan A. D'Aurora, Steubenville City Schools, bdaurora@scsohio.org
}

\begin{abstract}
Mobile technology is quickly becoming an integral tool of business intelligence in U.S. public school systems. While cost and implementation are budgetary concerns, advancement of such technology such as the iPad in the arena of public education is having influence on the academic and social experiences of students. This paper defines business intelligence and iPad technology. Additionally drawing on the research of Jensen and Morreale, it examines critical factors for academic success through a quantitative study of high school junior and senior students enrolled in a gifted program in the Steubenville, OH City School system, and presents findings on Attitude and Satisfaction on the use of iPad technology, Academic Engagement, Academic Performance, and Social Support.
\end{abstract}

Key Terms: iPad, Business Intelligence, Success Factors, High School, Technology Management, Gifted Education, College and Career Readiness, Attitude and Satisfaction, Academic Engagement, Academic Performance, Social Support

\section{INTRODUCTION}

Today (2015) in the United States, societal and governmental agendas are dictating that high school students be college and career ready more than they have ever been in the history of public education. College readiness is defined as the knowledge and skills that high school graduates must possess to be successful in college. These skills are the same as those needed to be successful in jobs that pay enough to support a family, provide benefits, and offer a clear pathway for career advancement through further education and training [12]. Concurrently, the demand for students to develop 21 st century skills is a driving force in education reform. The goal set for systems of public education is to produce students who are academically prepared and possess these desired skill sets so that the United States will produce a workforce capable of competing in the global workforce for careers, jobs, and placement in institutions of higher learning.

The purpose of this research is to determine the influence of iPad technology, as a form of business intelligence in public schools, has on college and career readiness on high school junior and senior students enrolled in a gift program. This case study employed a quantitative single instrument taking a deductive approach from the research of $[6,8]$. A secondary school district located in Jefferson County, Ohio was used to survey the junior and senior gifted students and their iPad usage to determine the influence on the readiness of their students for college and career. In specific, this study examined the academic preparation and social experiences and needs of these students and the influence that iPad technology had on them using the constructs of Attitude and Satisfaction, Academic Engagement, Academic Performance and Social Support. Data was collected through a questionnaire examining the use of iPads and other portable computing technology based on the research instrument and methodology of Compomizzi (2013).

\section{COLLEGE AND CAREER READINESS}

Starting from an early age, students exposed to STEM have demonstrated better performance than those who have not been exposed to STEM. According to the article, Unpacking the Benefits of a STEM Education, the Obama administration has made it a point to focus on expanding STEM education by providing nearly $\$ 3.1$ billion in funding, with the primary aim of producing well-versed students in the sciences and technology. Case studies have also shown that early introduction to STEM has impacted students career paths, with one particular case study pointing out how one student decided to pursue a degree in engineering at Washington State University, all as a result of his experience with STEM [23]. 
In July 2009, President Barack Obama set a goal for America again to have the highest proportion of college graduates in the world by 2020 [13]. In order to accomplish President Obama's American Graduation Initiative (AGI) goal, five million additional Americans must earn certificates, associate and bachelor's degrees. As indicated by the National Post-Secondary Education Cooperative (2012), during the 2012-13 school years, colleges and universities are expected to award 937,000 associate's degrees; 1.8 million bachelor's degrees; 756,000 master's degrees; and 174,700 doctoral degrees.

In a more recent study by the National Post-Secondary Education Cooperative (2012), 21.6 million students are projected to attend American colleges and universities; this record number is an increase of about 6.2 million since fall 2000. Approximately 7.4 million students will attend public 2-year institutions, and 0.5 million will attend private two year colleges. Approximately 8.1 million students are expected to attend public four year institutions, and about 5.6 million will attend private 4-year institutions. The recent record breaking college enrollments have been motivated by both escalations in the traditional college age population and increasing enrollment rates to be employable in the global economy of the 21 st century.

The changing global economy requires that states focus on postsecondary education and training as the goal for all students. Graduating from high school is no longer an adequate measure for future success. States collectively will need to produce an additional three million college credentials to meet the growing workforce demands. States are leading the charge to prepare all students to become college and career ready. States are focusing on higher order skills found in the common core standards to more rigorous graduation requirements; in general, state education leadership continue to increase expectations for all students [2].

National Governors Association (2009) defines college and career readiness: "A college- and career-ready student is an individual that is ready to succeed in entry-level, credit bearing, and academic college courses and in workforce training programs. College refers to two and four-year postsecondary schools. Workforce training programs pertain to careers that offer competitive, livable salaries above the poverty line; offer opportunities for career advancement; and are in a growing or sustainable industry."

Students who obtain college credit in high school through dual enrollment, dual credit, or Advanced Placement (AP) and International Baccalaureate (IB) programs are more likely to enroll in college and complete a degree. At the same time, students who earn a career certificate are better prepared for entry into a job or further training. Leaving high school with college credit or a career certificate not only shows that a student is ready for postsecondary success, but also provides a head start to that objective [25].

Regarding the influence of mobile technology on learning experiences, colleges and universities have undertaken initiatives with iPads and are identifying different benefits. Marmarelli and Ringle (2011) state that one goal of their study was to examine impacts iPad technology had on learning. This study reports iPads supporting the student learning experience with benefits like annotating ease and touch screen features. Additional universities experimenting with iPads include the University of Notre Dame, George Washington University, Princeton University, George Fox University, Cornell University, and the Illinois Institute of Technology. While most are conducting studies with specific sample populations of students, others like Seton-Hill University in Pennsylvania are conducting more broad based research. Further, while benefits are being identified, some challenges of portable computing technology, specifically iPads, are clear, also. The primary challenge is one of finances and the application subscription costs incurred by students. Benefits include ease of research capabilities, increased communication with class peers, completion of in-class tasks and note-taking, mobility and portability [4].

In another light, research continues to be available unveiling factors critical to student success especially among higher risk college students including those who are from low economic areas, who are from ethnic minorities and who are first generation enrollees. Jensen (2011) identified key factors for student success including academic performance, attitudes and satisfaction, academic engagement, and social and family support. A study by Morreale (2011) focused on motivation through factors like study skills, sense of belonging and social connectedness.

The purpose of this study explores if high school students enrolled in gifted programs in the Steubenville, Ohio City School system utilize iPad technology academically and socially, and, if so, the influence iPad technology has on their readiness for college and work through the constructs of Attitude and Satisfaction, Academic Engagement, Academic Performance and Social Connectedness. 
In this paper, iPad Technology and Business Intelligence (BI) are defined in order to promote understanding as to how each component works with the other in providing organizations, such as schools, with alternatives to their everyday processes affecting the academic and social experiences of gifted junior and senior students.

\section{iPad}

The new standards and expectations held for technology integration make its implementation into the classroom an absolute necessity. Their overwhelming popularity among students make integration of handheld technology a necessity for public school leaders to ensure students are college and career ready.

Handheld technology integration is beginning to occur in schools throughout the nation. Changes in federal and state legislation and regulations are supporting this transition. No Child Left Behind (NCLB) legislation, in Title II Part D: Enhancing Education Through Technology (EETT) Sec. 2402, specifically states:

- To promote initiatives that provide school teachers, principals, and administrators with the capacity to integrate technology effectively into curricula and instruction that are aligned with challenging State academic content and student academic achievement standards, through such means as high-quality professional development programs.

- PRIMARY GOAL- The primary goal of this part is to improve student academic achievement through the use of technology in elementary schools and secondary schools. [5]

Federal funding is attached to these national goals. In recent years, this funding supplied districts with funds for the acquisition of current technologies.

The iPad is one such portable computing device. Its most popular features include fast processing, flash storage and touch screen capability. It is light weight at approximately 1.5 pounds, and has a battery life often exceeding 10 hours after charging. Given this, iPad technology is making an impact on industry and now moving into the realm of public high school education and college and work preparation.

According to Michael Vizard, "B.I. is the only real instance where the existence of the iPad has changed the way people use a particular set of business applications. Apple's tablet makes it easier to flip through reports and gain valuable insights at a glance". According to Soumendra Mohanty, global lead for information management at Accenture, that's helping increase B.I. application usage while altering the way people work: "There's a lot more decision-making taking place outside the office, because people are accessing BI applications on mobile computing devices [22].”

In a BI survey by Dresner Advisory Services, 52\% of respondents who were primarily BI administrators and information technology managers indicated that mobile technology was either critically important or very important with many seeing it "as a must-have capability going forward and a potential game-changer for BI" [7].

iPad technology is built on Apple's mobile operating iOS system. This platform is built on the concept of humancomputer interaction through multi-touch gestures like swiping, pinching, and reverse pinching, touching, and tapping. Through these gestures, users can manipulate objects and presented data for analysis and, consequently, make decisions, communicate them, and publish them from virtually any location. Collectively, these capabilities are now being transferred and are more readily available to educational environments.

\section{STEUBENVILLE CITY SCHOOLS}

On the surface, Steubenville students appear to be achieving at stellar rates. In 2013, elementary students achieved grade level expectations in literacy at 91\% (Pugliese), 92\% (East Garfield), and 100\% (Wells Academy). At upper levels, the 4-year cohort graduation rate was reported at $94 \%$ - an amazing accomplishment, and has a dropout rate of $10.3 \%$ rate in four years, and $4.5 \%$ in five years. The average attendance rate is $96.9 \%$, and the chronic Absenteeism Rate: $13.7 \%$.

However, local district data indicates that only $62 \%$ of graduates went on to pursue college, vocational training, or a certification program. More than one-in-three students graduated from Steubenville High School without a career plan, employment prospects, or strategy in place to become economically self-sufficient. As is true of most communities, blue collar jobs are disappearing and 21 st century skills are crucial. Of those that enrolled in college, 
$45 \%$ were required to take part in remediation coursework. The need for remedial coursework at the college level is devastating for Steubenville's high-poverty population. Additional remedial classes mean that students will be unable to graduate from their selected program on time, jeopardizing financial aid and scholarships. The need to enroll in remedial coursework is the most frequently cited reason for college drop-out on surveys distributed and collected by the Steubenville counseling staff to track students post-graduation.

Evidence shows that young people desperately need enrichment programming, beginning in elementary school, to connect literacy skills with 21 st century skills such as Critical Thinking, Creativity, Communication, and Collaboration. An early focus on literacy and crucial 21 st century skills will prepare students from a young age to graduate from high school fully prepared to succeed at the college level.

Statistics from the 2008-2012 American Community Survey show that the amount of persons for whom poverty status was determined as poor was 11,328 out of a population of 67,274 , making the poverty rate $16.8 \%$, ranking Jefferson County, home of Steubenville City Schools, one of the highest poverty counties in the state of Ohio.

The 2013-2014 Ohio School Report Cards indicates that Steubenville City Schools has an overall enrollment of 2,281 students in the district. Of the 2, 281 students $97.8 \%$ (2, 232 students) are considered economically disadvantaged. The percentage of Black, Non-Hispanic students is $25.8 \%$ (588 students), multiracial is $12.3 \%$ (281) students, and White, Non-Hispanic is $60 \%$ (1,368 students). Steubenville City Schools has an overall minority percentage rate of $39.8 \%$ (908 students). Of the 2, 281 total students, $17.2 \%$ (392 students) have disabilities, and $100 \%$ of the students are eligible to receive free lunch. Consequently, Jefferson County's poverty level is widespread and overwhelming that Steubenville youth tend to leave after high school, or fall victim to an endless cycle of crime, teen pregnancy and illiteracy.

In the Steubenville City School system, gifted students receive iPads at the beginning of their junior year. The iPads are expected to prepare the students for success in their dual enrollment and college credit courses. Some barriers to the use of the iPads, however, exist because faculty training on methods which take advantage of mobile technology was minimal, teacher fear of the use of technology, ineffective elective device training for students and inconsistent student encouragement to use the device academically and socially. The courses that students use the iPads include: AP Literature, AP Trig \& Pre-Calculus, AP Chemistry, AP. American Studies I, Foreign Language, and dual enrollment courses in their senior year. The senior gifted student's courses include: College English, Calculus or AP Statistics, AP Physics or Biology II, American Studies II, College Anthropology, College Western Civilization, College Psychology, and College Sociology. Students are provided the opportunity to come in for individualized training on the devices, however, most students do not attend the training. Expected outcomes of using iPad technologies are improved academics, better school attendance rates and confidence in skills achieved and relationships built.

According to Ohio Dept. of Job and Family Services/Labor Market Information (2013) Access to Data for Steubenville, the amount of single family homes in Steubenville is $21.15 \%$ compared respectively to the state average of $17.19 \%$ and the national average of $17.68 \%$. The type of Steubenville family demographic is broken down into the following percentages: married families in Steubenville account for 38.84\% or 2, 840 people. Male only household equal's $3.19 \%$ or 286 males. Female only households contain $17.24 \%$ or 1, 260 females. Non-family households contain $35.13 \%$ or 2, 568 individuals of the total population for Steubenville. The median income for a household is $\$ 17,874$ compared to the state average of $\$ 25,424$, and the national average of $\$ 26,507$. The unemployment rate for Steubenville is $4 \%$ compared to the state and national average of $6 \%$. Steubenville City Schools graduates entering college for fall 2013 had 58 first time college students. $45 \%$ of those student enrolled in a Public University or University Regional Campus, $55 \%$ enrolled into a community college. $36 \%$ of the students were enrolled into developmental Math and English.

As indicated by the 2014 Ohio Remediation Report (2014), between 2009 and 2013, the number of Ohio public high school graduates matriculating into Ohio public colleges and universities decreased by 12.5 percent, dropping from 52,782 in 2009 to 46,151 in 2013. This decrease reflects a decrease in the high school age population in Ohio and other Midwest states. Figure 4 represents the Ohio Public High School Graduates Entering Ohio Public Colleges/Universities as First Time College Students. 


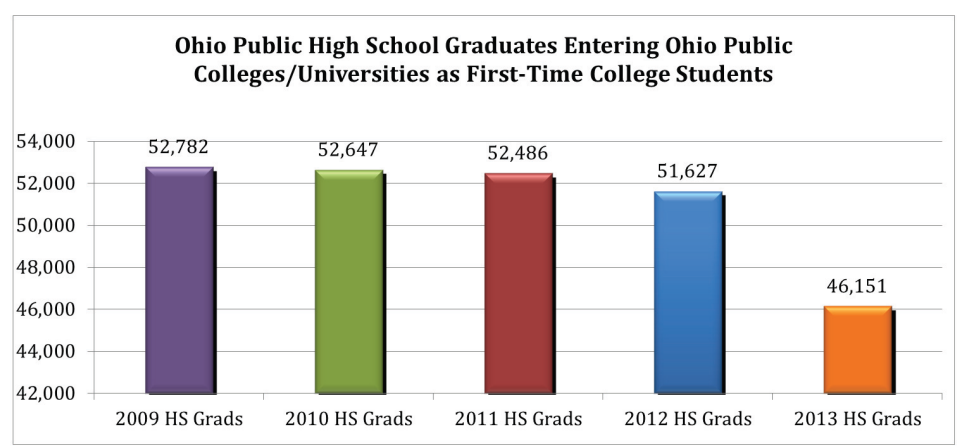

Figure 1. Ohio Public High School Graduates (ODE, 2014)

Steubenville City Schools has employed a model of continuous enrichment for their gifted education. The gifted students data and indicator highlight the opportunities for and performance of gifted students. Figure 1 indicates the amount of students identified as gifted and in what categories they fall. Figure 2 indicates of the identified gifted students, the amount that are receiving gifted services. Figure 1 provides additional information on the gifted students, including, the performance of the identified gifted students, and measures the opportunity and performance expectations for the gifted students.

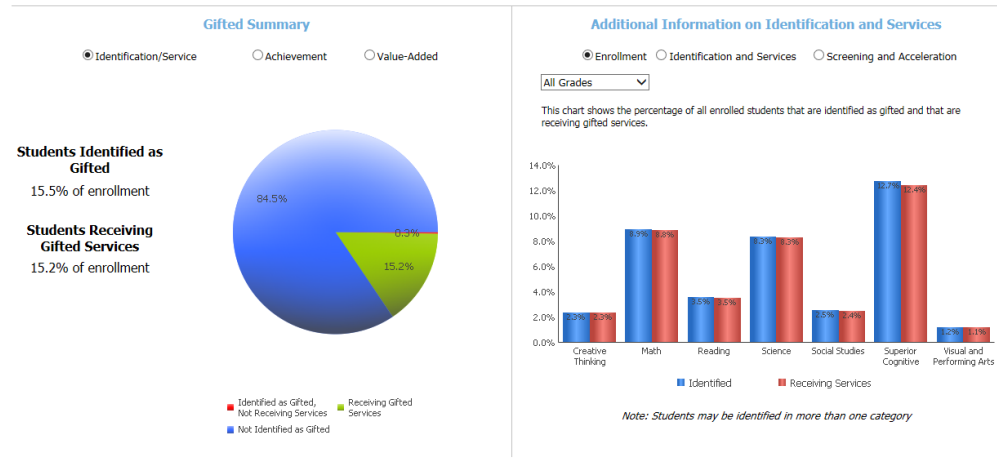

Figure 2. Gifted Students (ODE, 2014)

As indicated by the Ohio Department of Education Understanding the Report Card (2014), when students graduate from Ohio high schools, they must be ready for success in college and careers without needing to take remedial classes. This goal is measured by the Prepared for Success component.

Prepared for Success is a unique component. It contains six measures that do not receive a grade; they are only reported on the report card. The component grade is based on the percentage of a school's or district's four- and five-year graduation cohort that demonstrates college and career readiness. A student who has demonstrated college and career readiness as determined by the State Board of Education will be included in the measure.

The Prepared for Success component provides information on how schools prepare students for various pathways of college and career success. This indicator measures the following components: College Admission Test (participation rate and percent receiving non- remediation score), Dual Enrollment Credits (percent earning at least three credits), Industry Credentials (percent of students with a credential), Honors Diplomas Awarded (percent of students with an Honors Diploma) Advanced Placement (participation rate and percent scoring three or above) International Baccalaureate Program (participation rate and percent scoring four or above)[14].

This performance indicator provides insights on how those students do once they leave high school. What happens beyond the diploma is an important indicator of how well schools are preparing students. Figure 3 details the prepared for success indicator that Steubenville City Schools has received from the Ohio Department of Education Report Card. 


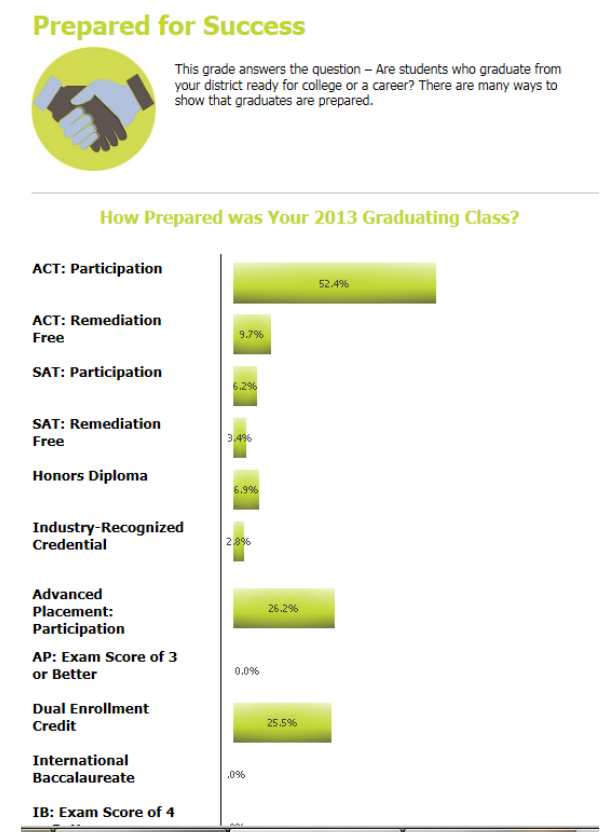

Figure 1. PreparedforSuccess(ODE,2014)

Steubenville City Schools has employed Career Pathways as a means of preparing all of its students for college and career readiness. While Career Pathways are not new to education, this is a new means of promoting students earning college credit while in high school, as well as industry credentials to prepare students for the workforce. As part of the Ohio Department of Education initiative, school districts in Ohio now have to offer career advising to its students in addition to college advisement. Students in Steubenville City Schools completed a career cluster inventory utilizing Ohio Means jobs.com, the inventory provided the district with the eight most common career pathways to begin the academic school year of 2015-2016 to offer to the students. The career pathways most interested were: Arts and Communication, Education and Training, Health Science, Hospitality and Tourism, Information Technology, Law and Public Safety, and Marketing. These pathways offer an overview of the various career options along with education and training that can begin as early as grade 7 [14].

\section{RESULTS}

Results from the survey instrument yielded a $56 \%$ response rate. Of the 50 junior and senior students surveyed, 28 responded to questions about their iPad usage. 57.14\% (16 of 28) are seniors aged, 24 of respondents are in the 1718 age range. Of the respondents, 18 are females and nine are males. 24 (92.31) are white; two indicated multiple races. 50\% have had an iPad for 13-24 months with the remaining 50\% less than 12 months.

Concerning utilization academically and socially, results of the survey conveys that when comparing desktop computers, smart phone technology, the iPad and laptop computers, the most frequently used device is the desktop with 36 of 50 responses; 20 of 50 respondents indicated that the iPad was their primary computing device. When considering Jensen's factor regarding Attitudes and Satisfaction as it applies to students who are at higher risk for academic success, however, $78.57 \%$ students in this study found the device ease to use and increasingly useful with $35.71 \%$ students stating that they enlist the use of their iPad between four and seven hours per day.

Specifically addressing the influence of iPad technology on the academic experience of these gifted students, the iPad is having positive influence. Of the total sample population, $75 \%$ of respondents agreed or strongly agreed that the iPad is a useful tool for school work. Regarding Jensen's factor of Academic Engagement and the research of Morreale on study skills, $60.72 \%$ of students indicated using the iPad frequently or always for research; $21.43 \%$ stated that they use their iPad frequently or always for completing homework assignments. Additionally, 50\% employed the iPad for in-class tasks such as note-taking and information look-up. Respondents also reported that of 
all the app's they downloaded, $50 \%$ of them were academically related app's such as iBooks, Free Books, Academy, Test Free, Yellowfin, and Puffin. Concerning completion of reading assignments, 18 of 50 students indicated that they prefer the iPad either frequently or always with another 18 students stating that they use their iPad at least occasionally to complete reading assignments. Finally, Jensen's Academic Performance factor was considered with GPA. Of the 28 students responding, 13 reported a GPA of 3.6-40, 13 indicated a GPA of 3.1-3.5, and two students recorded a GPA of 2.6-3.0. Related to the Pathway study indicators, $32.14 \%$ of students conveyed the intention to major in some area of health science and $21.43 \%$ of students reported intentions of majoring in education.

Regarding the factors of Social Support (Jensen) and Sense of Belonging (Morreale) among students who possess characteristics of higher risk for academic success, the influence of iPad technology on the students is yielding mixed results. As a tool for communications, $82.14 \%$ of the participants reported that they at least somewhat agree that the iPad is useful as a communications device or social interaction tool. Interestingly, though, 26 of the 28 respondents stated that either downloaded no apps or a few to socialize with others. Looking more closely, $21.43 \%$ indicated that they use their iPad to frequently communicate with school personnel, academic advisors and counselors; $17.86 \%$ reported using the iPad to communicate frequently with teachers; and $10.71 \%$ conveyed using the iPad to communicate with classmates for assignments and school work. As far as communications with school organizations and clubs, though, only six of 28 students reported enlisting the iPad at least occasionally, but the remaining 22 participants indicated that they seldom or never use it for this function. Similarly, six students conveyed that they use the iPad to communicate with non-school activities and organizations with $78.57 \%$ stating that they never or seldom use it for this purpose. For communications with non-school personnel such as family and friends, $35.71 \%$ utilize the iPad for at least occasional communication. Finally, as a social interaction tool, 39.28\% of responses conveyed that they iPad is used at least occasionally to play games with others, and $40.74 \%$ indicated that the iPad is employed to watch videos and listen to music with others.

\section{CONCLUSIONS}

Technology integration is often viewed dichotomously; it either exists or it does not. However, recent studies indicate it is not just whether the technology devices are present or not, it is whether the integration into the pedagogy has made a transformation in students' academic practices, communications routines, social interaction habits, and achievement levels. Specifically, as more school districts introduce iPad technology to business intelligence toolboxes, the influence of mobile technology on the academic and social experiences on students continue to be observed and measured.

$21^{\text {st }}$ century skills, such as the ability to academically form and articulate a vision and the interpersonal skills of communication and collaboration, are determined to be essential leadership skills for the continued implementation of iPad technologies in the classrooms. As this study with juniors and seniors enrolled in the gifted program at Steubenville City Schools iPad technology discloses while the iPad is not the primary device employed by these students academically and socially, the technology is having effect. Addressing the described barriers regarding student training, teaching method enrichment, and consistent encouragement of use of the device by Steubenville City Schools District will expand the implementation of 1:1 devices for all students and may lead to greater influence academically and socially on students. For, as the study evidence indicates regarding academic influences, the more hours the iPad is used, the more valuable the perception as an academic tool for functions such as reading, note-taking, completion of in-class tasks, research, and completion of homework. As a communications tool, iPad technology is breaking through as a means of interaction between school personnel and students. More work has to be done in making the technology a viable means of social support with school organizations.

Further, as other research indicates, public school districts are able to see the benefit of the mobile devices in the area of student engagement and increasing opportunities for their students to be college and career ready after graduation. Education is in a time of reform and change. Mandates require alignment of education with the technological advances of the 21 st century and skills needed to interface with them as students matriculate into college and careers. With recent federal and state mandates, new teacher evaluation methods and the economic crunch on public school district resources, integration of mobile technologies, like the iPad, becomes an unavoidable and integral part of the educational business intelligence toolbox. 


\section{REFERENCES}

1. ACT, "2009 Percent of ACT-Tested Graduates Ready for College-level Coursework by State" (Iowa City, IA: ACT, 2009). Available at: http://www.act.org/news/data/09/collegeready-text.html

2. Carnevale .A, Smith. N, and Strohl. J, (2010). Help Wanted: Projections of Jobs and Education Requirements Through 2018 (Washington, D.C.: Georgetown University, Center on Education and the

3. Workforce, 2010). Available at: http://www9.georgetown.edu/grad/gppi/hpi/cew/pdfs/FullReport.pdf

4. Compomizzi, J. (2013). The Influence of iPad Technology on the Academic and Social Experiences of Military and Veteran Students. UMI (Publication No. 3565603).

5. Enhancing Education Through Technology Act of 2001, 20 U.S.C. § 2401-2404 (2008).

6. Jensen, U. (February, 2011). Factors influencing student retention in higher education. Summary of influential factors in degree attainment and persistence to career or further education for at-risk/high educational need students. Kamehameha Schools Research \& Evaluation. Pacific Policy Research Center. Honolulu, HI.

7. Lautzenheiser, D. (December 1, 2010). Mobile BI: how to run your business on the iPad. Retrieved from http://www.enterprisemobiletoday.com.

8. Marmarelli, T. and Ringel, M. (2011). The reed college iPad study. The reed institute. Retrieved September 10, 2011 from http://134.10.15.75/cis/about/ipad_pilot/Reed_ipad_report.pdf.

9. Mechur Karp, M., et al., (2007). "The Postsecondary Achievement of Participants in Dual Enrollment: An Analysis of Student Outcomes in Two States" (St. Paul, Minn., National Research Center for Career and technical education, university of Minnesota, 2007). Available at: http://ccrc.tc.columbia.edu/Publication.asp?UID $=547$

10. Morreale, C. (July, 2011). Academic motivation and academic self-concept: Military veteran students in higher education. Ph.D. dissertation, State University of New York at Buffalo, United States -- New York. Retrieved August 30, 2011, from Dissertations \& Theses: A\&I.(Publication No. AAT 3460783).

11. National Governors Association, "Common Core State Standards Initiative: Standards- Setting Criteria" (Washington, D.C.: 2009). Available at: http://www.corestandards.org/assets/Criteria.pdf

12. National Center for Education Statistics. (2008). "Community Colleges: Special Supplement to the Condition of Education 2008" U.S. Department of Education. Retrieved from http://nces.ed.gov/programs/coe/2008/analysis/2008033.pdf

13. Obama, B. (2009). "Remarks of President Barack Obama - as prepared for delivery address to joint session of congress.” The White House. Retrieved from http://www.whitehouse.gov/the_press_office/remarks-ofpresident-barack-obama-address-to-joint-session-of-congress

14. Ohio Report Card (2014). Ohio Department of Education. Retrieved from: http://reportcard.education.ohio.gov/Pages/District-Report.aspx?DistrictIRN=044826

15. Ohio Remediation Report (2014). Ohio Department of Education. Retrieved from: https://www.ohiohighered.org/sites/ohiohighered.org/files/uploads/reports/2014-Ohio-RemediationReport_FINAL.pdf

16. Ohio Department of Education Status of Ohio Graduates Remediation Report by District (2013). Ohio Board of Regents University Systems of Ohio. Retrieved from: https://www.ohiohighered.org/sites/ohiohighered.org/files/uploads/data/hs_transition/--2013-OhioRemediation-Report.pdf

17. Ohio Department of Education Career Pathways (2015). Retrieved from: http://education.ohio.gov/Topics/Career-Tech/Career-Connections/Career-Pathways

18. Ohio Department of Education Ohio Poverty Report (2014). Retrieved from: ODJFS/LMI (Ohio Dept. of Job and Family Services/Labor Market Information), 2013 Unemployment rates found at http://lmi.state.oh.us.

19. Ohio Department of Education Understanding Ohio's School Report Card (2014). Retrieved from: http://education.ohio.gov/getattachment/Topics/Data/Accountability-Resources/The-A-F-Report-Card-20142.pdf.aspx

20. S. Bureau of the Census - ACS, 2003-2013 2002-2012 American Community Survey 1-yr. period data for Ohio and the U.S. found at http://www.census.gov. Summary file tables P114 and P116 for 2002 and 2003, and summary file tables B17001, B17002, B17010,B17015, B17016, C17001-C17003, C17010, and C17001A-I for subsequent years; also B19101 in 2013.

21. Slentz, K. (2012, August). Changing practice, changing culture through NYSED. Presented at the annual educational leadership doctoral cohort welcome dinner of The Sage Colleges, Albany, NY. 
22. Vizzard, Michael (May 7, 2012). Apple iPad Is Evolving the Business Intelligence Market. Retrieved from http://slashdot.org/topic/bi/apple-ipad-is-evolving-the-business-intelligence-market/

23. Wagner University (2015). Why is STEM important?. Retrieved from: https://wagner.edu/community/uncategorized/why-is-stem-important/

24. Wakelyn, D. (2009) Raising Rigor, Getting Results: Lessons Learned from AP Expansion (Washington, D.C.: National Governors Association, 2009). Available at: http://www.nga.org/Files/pdf/0908APREPORT.PDF.

25. Western Interstate Commission for Higher Education, 2012. Knocking at the college door: Projections of high school graduates 8th edition and supplements. Retrieved from http://www.wiche.edu/info/publications/knocking- 8th/knocking-8th.pdf 